\title{
Contamination caused by radium discharged with mine effluents into inland waters
}

\author{
B. Michalik, M. Wysocka, S. Chałupnik, K. Skubacz, A. Mielnikow \\ and L. Trząski
}

\author{
CENTRAL MINING INSTITUTE, 40-166 Katowice, Plac Gwarków 1, Poland
}

\begin{abstract}
One of the most serious problems occurring during coal extraction in Upper Silesia in Poland is caused by waters with very high salinity. These waters often contain also high concentrations of natural radionuclides, mainly ${ }^{226} \mathrm{Ra}$ from uranium series and ${ }^{228} \mathrm{Ra}$ from thorium series. At least $70 \%$ of the total amount of radium carried by this waters remains nowadays in underground galleries as radioactive deposits. But, during the period of the most extensive coal extraction up to $225 \mathrm{MBq}$ of ${ }^{226} \mathrm{Ra}$ and $400 \mathrm{MBq}$ of ${ }^{228} \mathrm{Ra}$ were released daily into surface along with the other mine effluents. As a result of discharge of radium-bearing waters into settling ponds and later into rivers a significant increase of radium concentration in bottom sediments has been observed. Sometimes there is also a contamination of river beds, soils and biota. The paper describes results of investigation of waters and sediments with enhanced natural radioactivity, that occur in settling ponds, where mine waters have been dumped. Measurements of different factors of radiological hazard were made, such as radium content in the soil from ponds' banks, variations of gamma radiation background and radon exhalation. Additionally radium transfer to vegetation that had transgressed into the ponds has been calculated.
\end{abstract}

\section{INTRODUCTION}

The Upper Silesian Coal Basin (USCB) is located in the southern part of Poland and there were up to 65 underground coal mines. Total outflow of waste waters from these mines reached $900000 \mathrm{~m}^{3} /$ day. Due to their very high salinity (sometimes higher than $200 \mathrm{~g} / \mathrm{l}$ ) they have caused severe damages to the natural environment. Additionally, these waters have often elevated concentrations of radium isotopes ${ }^{226} \mathrm{Ra},{ }^{228} \mathrm{Ra}$ and their decay progeny. This phenomenon has been recognized since the 1960 's [1]. Such waters have been found also in German coal mines [2,3] and it is very well known that the oil and gas extraction industry $[4,5,6]$ produces saline waters with enhanced radium concentration, too.

In USCB waters with high radium concentration occur mainly in the southern and central part of the coal basin, where coal seams are overlaid by a thick layer of impermeable deposits. The occurrence of enhanced natural radioactivity in Polish coal mines creates a potential radiation hazard for mining crews. In the underground mining industry in Poland, monitoring of the radioactivity of mine waters and precipitates, as well as gamma doses and radon progeny in air, is obligatory since 1989. The monitoring system has provided an opportunity to obtain a complete balance of radium occurrence in each particular mine and its influence on the surrounding natural environment. Investigation done by Tomza and Lebecka [7] showed that concentration of radium in formation water is correlated with its salinity and it has been found that the behavior of radium during transportation of radium-bearing brines in the gutters of underground galleries, settling tanks and ponds, pipelines and rivers depends mainly on chemical composition of the brines. But to some extend also on the conditions in the environment where the waters are transported through, for example on the presence of other waters of different chemical composition. Since the chemical composition of brines is so 
essential for further transportation of radium, two types of radium-bearing waters have been distinguished [8]. Waters type A contains not only radium ions but barium ions as well. Concentration of barium in these waters is at least six orders of magnitude higher than that of radium and reaches $2 \mathrm{~kg} / \mathrm{m}^{3}$. High barium concentrations enable co-precipitation of radium with barium sulphate when radium-bearing water type $\mathrm{A}$ is mixed with another water containing sulphate ions, which are very common in nature. In case of radium-bearing waters type B, where barium ions are not present, concentration of radium ions is too low to enable precipitation of radium sulphate because concentration of $\left[\mathrm{Ra}^{2+}\right] *\left[\mathrm{SO}_{4}^{2-}\right]$ does not exceed the solubility product. Due to differences in their chemical proprieties, the effect of release of radium-bearing waters type A and type B into the natural environment is completely different. Radium from radium-bearing waters type A is precipitated out in underground mine workings and in settling ponds, pipelines and little rivers. Concentration of radium in such precipitates is usually high reaching $400 \mathrm{kBq} / \mathrm{kg}$ in underground galleries and $270 \mathrm{kBq} / \mathrm{kg}$ on the surface [9], (in comparison, average radium content in soil is $25 \mathrm{~Bq} / \mathrm{kg}$ ) but the precipitation and sedimentation takes place rather close to the point where radium-bearing waters type A mix with waters containing sulphates, so that in the distance over few or several kilometres downstream from the discharge point of mine water the river water is free of radium. In opposite, from radium-bearing waters type B radium is not precipitated but transported with water to large rivers. Although, concentrations of radium in bottom sediments are in this case not very high, contamination of river waters and bottom sediments is observed over a large distance even up to hundred kilometres from the discharge point [10].

\section{THE BALANCE OF RADIUM INFLOWING INTO UNDERGROUND WORKINGS}

Concentration of radium isotopes in original water samples from different coal mines varies in a very wide range, from values merely exceed 0 up to $110 \mathrm{kBq} / \mathrm{m}^{3}$ or from 0 to $70 \mathrm{kBq} / \mathrm{m}^{3}$ for ${ }^{226} \mathrm{Ra}$ and ${ }^{228} \mathrm{Ra}$ respectively. Waters with radium concentration above $1.0 \mathrm{kBq} / \mathrm{m}^{3}$ have been found in 43 out of 65 coal mines in Upper Silesian Coal Basin. The highest concentration of ${ }^{226} \mathrm{Ra}$ has been ever measured was above $390 \mathrm{kBq} / \mathrm{m}^{3}$ [8].

The assessment of the balance of radium isotopes inflowing with waters into underground mine galleries can not be very precise. Even within the same mine there are inflows of water with different salinity, flow rate, chemical composition and radium concentration. The assessment of total amount of radium is especially difficult in mines where waters type A occur, because radium and barium always co-precipitate as sulphates, when such waters are mixed with any water containing sulphate ions. Such process very often spontaneously occurs in underground galleries and leads to creation of insoluble deposits with enhanced radium content. The approximate amount of ${ }^{226} \mathrm{Ra}$ in water inflows in coal mines in USCB have been calculated as high as $650 \mathrm{MBq}$ /day (i.e. $240 \mathrm{GBq}$ per year) while for ${ }^{228} \mathrm{Ra}$ this value is of about $700 \mathrm{MBq} /$ day or $255 \mathrm{GBq}$ per year. Although radium concentrations in waters type $\mathrm{B}$ are usually lower than in waters type $\mathrm{A}$ the total inflows to mines where radium-bearing waters type B occur are much higher so that the total activity of radium carried with water type B is slightly higher. The highest values for a single mine (with waters type $\mathrm{B}$ ) were: $78 \mathrm{MBq}$ per day of ${ }^{226} \mathrm{Ra}$ and $145 \mathrm{MBq}$ per day of ${ }^{228} \mathrm{Ra}[11]$.

\section{ANALYSIS OF RADIUM OUTFLOWS FROM COAL MINES}

Calculation of radium balance in waters dumped from coal mines to inland waters is more accurate, because of better evidence of such information as flow rates. The assessment of the total activity of radium released from coal mines in Upper Silesia with waste water is based on the results of determination of radium isotopes in waters released by collieries and data on amount of water released by individual mines. Samples of discharged waters were taken from settling ponds. In outflows from these ponds in $87 \%$ mines ${ }^{226} \mathrm{Ra}$ concentration exceeds $0.008 \mathrm{kBq} / \mathrm{m}^{3}$, in $25 \%{ }^{226} \mathrm{Ra}$ concentration is higher than $0.1 \mathrm{kBq} / \mathrm{m}^{3}$ and in $8 \%$ exceeds permissible level - i.e. $0.7 \mathrm{kBq} / \mathrm{m}^{3}$. In rivers enhanced 
concentrations of radium can be observed many kilometres downstream from the discharge points. This is mainly true for radium-bearing waters type $\mathrm{B}$, because out of these waters radium is not easily precipitated. The highest value of ${ }^{226}$ Ra concentration in river water was as high as $1.3 \mathrm{kBq} / \mathrm{m}^{3}-$ it was found in a small stream near it's conjunction with the Vistula River. By 1987, up to $400 \mathrm{MBq}$ per day both isotopes of radium had been being discharged into surface waters. The significant decrease of daily discharge of radium can be seen in the period 1987 -1995. There were two reason of this effect. Firstly, the purification of A type mine waters has been started in several coal mines in catchments areas of the Olza River and the Upper Vistula. The another reason was due to economical changes in the mining industry - dewatering of deep mines was more and more expensive and hydro-technical solutions have been applied in numerous mines to reduce water inflows into underground galleries, with special emphasis on brines.

In the last period the decrease of radium activity in discharge waters is mainly due to the purification of B type brines in collieries with the biggest radium inflows. The implementation of the treatment technology for the whole horizon in one particular mine caused the decrease of radium release by $150 \mathrm{MBq} /$ day $\left(60 \mathrm{MBq} /\right.$ day of ${ }^{226} \mathrm{Ra}$ and $90 \mathrm{MBq} /$ day of $\left.{ }^{228} \mathrm{Ra}\right)$. The application of the purification technology in other collieries should further reduce radium discharge.

The assessment of the balance of radium inflow and outflow shows that nowadays up to $80 \%$ of total activity of ${ }^{226} \mathrm{Ra}$ and $60 \%$ of ${ }^{228} \mathrm{Ra}$ remain in underground workings in a form of deposit precipitated out of radium-bearing waters either due to unintended mixing of natural waters of different chemical composition or due to the planned purification of radium-bearing waters. Deposits with radium concentration exceed $10 \mathrm{kBq} / \mathrm{kg}\left({ }^{226} \mathrm{Ra}+{ }^{228} \mathrm{Ra}\right)$ were found in 19 out of 65 Upper Silesian coal mines. Deposits with radium concentration over $100 \mathrm{kBq} / \mathrm{kg}$ were found in underground galleries of 5 coal mines and on the surface in the vicinity of two ones.

\section{RADIUM IN SURFACE SETTLING PONDS}

As it was written before, from waters type A radium is easily co-precipitated with barium as sulphates when mixed with other natural waters containing sulphate ions. The contamination takes place not only in underground workings but also on the surface, in the settling ponds or alongside streams or rivers into which radium-bearing waters are released [10]. In case of radium-bearing waters type B, there is no carrier for radium, therefore precipitation does not occur but only dilution in rivers and adsorption on river bed sediments.

In the hard coal exploitation process the main purpose of such ponds is to allow mechanical suspensions to settle, but by the way deposition of radium takes place there. The sediments with concentration of both radium isotopes exceeding $200 \mathrm{~Bq} / \mathrm{kg}$ were found inside 25 settling ponds. The total capacity of all these settling ponds reaches 5 millions cubic meters [12]. Two settling ponds have been investigated in detail. Both of them were located in the catchments area of the Vistula River. The first reservoir had been being used for 19 years, since 1980, as a settling pond for type B waters. During this period about 227 million $\mathrm{m}^{3}$ of waters had been discharged into it then released into the local stream, a small tributary of the Vistula River. Into the second pond waters type A were discharged and then released directly to the Vistula River. The use of this pond started in 1977. Since then about 72 million cubic meters of saline waters have been pumped into the reservoir. The total amount of the suspension, deposited in the pond, was calculated as $100000 \mathrm{~m}^{3}$ (about 150000 tons).

The assessment of the radium concentrations $\left({ }^{226} \mathrm{Ra}+{ }^{228} \mathrm{Ra}\right)$ in inflows to the first settling pond resulted in an annual activity of about $124 \mathrm{GBq}$ [13]. The calculated average radium concentrations in waters discharged to the pond was $3.6 \mathrm{kBq} / \mathrm{m}^{3}$ for ${ }^{226} \mathrm{Ra}$ and $6.2 \mathrm{kBq} / \mathrm{m}^{3}$ for ${ }^{228} \mathrm{Ra}$. The average radium concentration in outflows from this settling pond were similar to the values at inflow $-3.5 \mathrm{kBq} / \mathrm{m}^{3}$ for ${ }^{226} \mathrm{Ra}$ and $6.0 \mathrm{kBq} / \mathrm{m}^{3}$ for ${ }^{228} \mathrm{Ra}$. This means that only small amounts of radium have been being deposited at the bottom. By comparing the results of radium analysis of inflows and outflows for this reservoir it was calculated that only $2.9 \%$ of the ${ }^{226} \mathrm{Ra}$ and $3.3 \%$ of ${ }^{228} \mathrm{Ra}$ activities remain in the pond and are adsorbed on the bottom sediments. Sediments from this pond showed radium ${ }^{226} \mathrm{Ra}$ concentrations in the range $95-950 \mathrm{~Bq} / \mathrm{kg}$, and ${ }^{228} \mathrm{Ra}$ from 124 up to $1705 \mathrm{~Bq} / \mathrm{kg}$ [14]. 
Into the second pond type A waters were discharged. The inflows of sulphate rich groundwater were small but numerous, therefore precipitation of $\mathrm{BaSO}_{4}+\mathrm{RaSO}_{4}$ occurs in the pond. The water outflows from this pond directly into the Vistula River. The radium input for this reservoir was assessed as approximately $9.5 \mathrm{GBq} / \mathrm{year}$. The maximum radium content in sediments occurred near the outlet of the pipeline that transported water from the mine to the settling pond. The total activity of radium isotopes $\left({ }^{226} \mathrm{Ra}+{ }^{228} \mathrm{Ra}\right)$ here was $55 \mathrm{kBq} / \mathrm{kg}$. On average the radium content was much lower, and its distribution was very non-uniform. In some places the radium concentration in sediments was the same as in the earth crust $(25 \mathrm{~Bq} / \mathrm{kg})$.

The above results can be used to describe the radium behaviour in settling ponds and rivers and then for the attempt to correlate it with the chemical composition of radium-bearing waters. In the case of the first reservoir, the rate of deposition of radium was very low, only about $7 \%$ of the total activity was adsorbed in bottom sediments per year. The distribution of radium in the sediments was rather uniform, therefore calculation of radium balance in sediments was relatively easy. At least $90 \%$ of the radium has been discharged into inland waters. This process leads to the contamination of river water a long way from the discharge point.

The rate of radium deposition in the second settling pond was much higher, because of the different type of water - type A with elevated barium content. The assessment of the deposition rate for radium was also difficult. Calculations made in two different ways gave different results. Taking into account the measurement of radium concentrations in the inflows we obtained the value of about $350 \mathrm{GBq}$ for the whole period of operation. Another method of calculation, based on the amount of radium in the bottom deposits and measurements of radium concentrations in outflows, gave a result more than two times higher $-810 \mathrm{GBq}$. In the latter case the average concentration of radium isotopes in waters released to the pond during the whole period of operation was roughly $10 \mathrm{kBq} / \mathrm{m}^{3}$. This relates to a deposition of about $39 \%$ and contrasts with the $90 \%$ calculated using the first approach. For type A waters the deposition rate depends strongly on the amount of groundwater inflow, as well as the sulphate ion content.

The radiation risk to members of the public caused by these phenomena, in spite of very wide range of observed mass specific activity of radium in the sediments, is rather low. Currently all the settlings ponds lay on the areas that belong to particular collieries. Access to these areas are restricted to authorized personnel this is why the potential exposure to external radiation is limited only to staff engaged in certain practices and ultimately, controlled in the frame of occupational risk monitoring. Additionally, during normal exploitation, settling ponds are filled with water that constitutes a cover against external radiation from the bottom sediments. A serious problem will emerge in the near future when the mines will be closed.

\section{IMPACT OF CONTAMINATED SETTLING PONDS INTO RADIOLOGICAL RISK IN ENVIRONMENT}

Enhanced radium concentration in bottom sediments collected in mine settling ponds can cause significant impact on radiation risk in surrounding environment. One of the most important problems is radon exhalation, especially when the area of interest is intended to be used as a site for dwelling houses. Besides this, during planning of surface settling ponds' land reclamation the variations of gamma radiation background and radium transfer to food chain should be taken into account. For the assessment of the possible enhancement of radiation risk investigations of three surface settling ponds being under different stage of closure operation have been carried out. At the test sites the measurements of the variations of the natural gamma radiation background and the gamma spectrometric analyses of the settling pond bottom sediment samples have been made. In one of the ponds being under study, where the natural plant ingress had taken place, the measurements of radium isotopes content of the plant samples were taken. 


\subsection{Settling pond $A$}

The measurements in the settling pond A were being taken during its filling with waste rock. The spectrometric analysis of the pond's bottom sediments has shown that the maximum radium ${ }^{226} \mathrm{Ra}$ concentration was around $3.0 \mathrm{kBq} / \mathrm{kg}$. The measurements of radon exhalation coefficient were taken both in the part of the pond where the bottom sediments were just covered by a waste rock layer of more then $10 \mathrm{~m}$ thick and in the part of pond where the dried bottom sediments had not before been covered by any isolating layer. The radon exhalation coefficient measured over the dried bottom sediment amounted to about $12 \mathrm{mBqm}^{-2} \mathrm{~s}^{-1}$. The radon exhalation coefficient in the covered part of the pond were low and did not exceed a value of $2 \mathrm{mBqm}^{-2} \mathrm{~s}^{-1}$, as compared with the value of $3.4 \mathrm{mBqm}^{-2} \mathrm{~s}^{-1}$ obtained from measurements at the nearby old waste rock dumping ground. It is to be expected that drying and afterwards covering of the pond's bottom sediments by waste rocks from the adjoining heap can be a satisfactory protection measure against the radon gas emission.

In the vicinity of the pond the disturbances of the natural gamma radiation background has been measured. The gamma dose rates ranged from 0.1 to $0.2 \mu \mathrm{Sv} / \mathrm{h}$ and appeared to be slightly higher than the corresponding average values for the area of Upper Silesia.

\subsection{Settling pond $B$}

In case of the second pond the results of the spectrometric analysis have shown that in the bottom sediments maximum radium ${ }^{226} \mathrm{Ra}$ and ${ }^{228} \mathrm{Ra}$ concentrations amounted to $2.0 \mathrm{kBq} / \mathrm{kg}$ and $4.0 \mathrm{kBq} / \mathrm{kg}$ respectively. The measurements of the radon exhalation were made under different weather conditions in the years $2002-2003$. The obtained values of the radon exhalation coefficient ranged from around $2 \mathrm{mBqm}^{-2} \mathrm{~s}^{-1}$ to more than $200 \mathrm{mBqm}^{-2} \mathrm{~s}^{-1}$. It is important to note that during whole first year of investigations sediments of settling pond $\mathrm{B}$ were wet and the radon emission only took place from their thin subsurface layer, the thickness of which ranged approximately from 0.1 to $0.2 \mathrm{~m}$. In the second year of measurements, the settling pond's bottom was being dried enough to allow us to perform investigation throughout most of the pond's area. The results from measurements made in summer period following a longer rainless period, indicated that radon gas emission measured at the most intensely dried sites of the settling pond exceeded the previous year's emission. The highest measured value reached $300 \mathrm{mBqm}^{-2} \mathrm{~s}^{-1}$. The succeeding measurements showed that high radon emission persisted even after rainfall periods - about $100 \mathrm{mBqm}^{-2} \mathrm{~s}^{-1}$. The values of the radon exhalation coefficient measured in the vicinity of the settling pond did not exceed $3 \mathrm{mBqm}^{-2} \mathrm{~s}^{-1}$. The gamma dose rates many times exceeded the average value for either Upper Silesia or the whole area of Poland and ranged from 0.6 to $2.6 \mu \mathrm{Sv} / \mathrm{h}$.

In order to investigate the influence of the settling pond B on the ecosystem the samples of the vegetation that began to overgrow the dried bottom sediments were collected. The vegetation transgression commenced in spring 2003, starting from the dried places where the salt water from the subsurface layer was either washed out or diluted by precipitation. During three seasons of observation the overgrown area has visibly increased. Currently there are several zones of the pond of interest are covered by plants. Some parts of the pond's banks and bottom are overgrown by irregular clusters of vegetation, i.e. Atriplex hastatum L., Puccinellia distans (Jacq.) Parl., Spergularia salina Presl. (three species typical for salinated soil), and Chenopodium glaucum L. Polygonum aviculare L. Samples of plants growing on the bottom sediments at some distance of the pond bank were collected. The radium ${ }^{226} \mathrm{Ra}$ and ${ }^{228} \mathrm{Ra}$ isotope content of the plants were determined by gamma spectroscopy. According to archive data the radium concentrations in grass samples collected in the vicinity of settling pond $\mathrm{B}$ do not exceed $5 \mathrm{~Bq} / \mathrm{kg}$. However current investigations of plant samples collected from the bottom sediments show the radium concentrations reaching the values of $580 \mathrm{~Bq} / \mathrm{kg}$ and $1136 \mathrm{~Bq} / \mathrm{kg}$ for radium ${ }^{226} \mathrm{Ra}$ and ${ }^{228} \mathrm{Ra}$ (dry mass) respectively. 


\subsection{Settling pond $C$}

To compare situations arising at various settling ponds abandonment stages the measurements were made in settling pond C. The pond was evacuated in 1980's and the sediments were moved to an old sand pit and than the water started again being discharged into the empty settling pond. The sediments from the pond's dredging operation showing radium ${ }^{226} \mathrm{Ra}$ concentration values in excess of $100 \mathrm{kBq} / \mathrm{kg}$ were covered with the waste rock forming, in course of time, a heap of refuse about $20 \mathrm{~m}$ height. The measurements of radon exhalation were taken on both the waste rock pile covering the sediments and the active settling pond bank. On the settling pond bank radon exhalation coefficient reached values of about $20 \mathrm{mBqm}^{-2} \mathrm{~s}^{-1}$ while on the waste rock pile the corresponding values did not exceed $2 \mathrm{mBqm}^{-2} \mathrm{~s}^{-1}$. In the vicinity of the settling pond natural gamma radiation background perturbation measurements were made as well. Just as in the case of radon exhalation, the ambient dose equivalent rates were higher for the pond bank and lower for the waste rock pile. The obtained values are lower than those typical for settling pond B, but they still can many times exceed the average values for Upper Silesia. The waste rock covered sediments, at present, pose no radiation hazard for the natural environment. However it is important to note that if these sediments are exposed, as a result for instance of the waste rock pile stripping to recover rock material for use in highway engineering, the radon emission will be intensified, the natural gamma radiation background will be perturbed and the radium will even transfer to plants.

\section{SUMMARY}

- The underground mining of coal sometimes causes a significant enhancement of the natural radioactivity in the environment. It is mainly the result of release of radium-bearing waste waters from coal mines, as well as the storage on the surface of solid waste products with enhanced natural radioactivity. This phenomenon is observed not only in the Upper Silesian Coal Basin (USCB) but also in Germany and in other countries.

- A significant part of the radium, released with mine water into settling ponds on the surface, is transported into rivers. This pathway of contamination of the natural environment is very important in the catchments area of the Vistula River, the biggest one in Poland.

- In certain settling ponds significant amounts of radium isotopes have accumulated during their operation. There is an increase of radiation risk in the vicinity of such ponds and contamination of the banks of these reservoirs.

\section{References}

[1] M. Saldan, Biuletyn Instytutu Geologicznego, Warszawa, Poland, vol. 5. (in Polish), (1965).

[2] I. Gans, Radium in waste water from coal mines and other sources in FRG. Proc. of the Second Symposium on Natural Radiation Environment, Bombay, India (1981)

[3] J. Wiegand, Radioactive contamination of surface waters, sediments and soil caused by coal mining in the Ruhr District (Germany), Proceedings of the NORM IV Conference, Szczyrk Poland 2004.

[4] B. L. Dickson et. al. - Evaluation of the Radioactive Anomalies Using Radium Isotopes in Groundwaters - Journal of Geochemical Exploration, Vol. 19, p. 195.

[5] L. K. Gucalo, O niekotorych zakonomiernostiach raspredielenija radia w podziemnych wodach sredniej czasti Dnieprowsko-Donieckoj Wpadliny, Gieochimja, 12, 1305-1312 (in Russian).

[6] K. P. Smith et al. Radiological dose assessment related to management of NORM generated by petroleum, industry, EAD Argonne National Laboratory, Argonne, Illinois, USA 1996.

[7] I. Tomza, J. Lebecka, Radium Bearing Waters in Coal Mines. Proc of Int. Conf. on Radiation Hazard in Mining. Golden, Colorado, USA, (1981). 
[8] J. Lebecka, K. Skubacz, S. Chałupnik, M.Wysocka, Radioactive contamination of the natural environment in the Upper Silesia caused by mine waters and radioactive deposits - Wiadomosci Górnicze, no. 6, p.23, Katowice 1991 (in Polish).

[9] J. Lebecka, K. Skubacz, S. Chalupnik, I. Tomza, I. Pluta, Influence of Mining Activity on Distribution of Radium in the Natural Environment, Proc. of $4^{\text {th }}$ Working Meeting Isotopes in Nature, Published by Academy of Sciences of the GDR, Central Institute of Isotope and Radiation Research, Leipzig, Part II, p. 423, (1987).

[10] J. Lebecka, A.Mielnikow, S. Chalupnik, M. Wysocka, K. Skubacvz, B.Michalik, Radium in mine waters in Poland: occurrence and impact on river waters - Proceedings of the Natural Radiation Environment VI, Montreal, in: Environment International 1996

[11] S. Chalupnik, M. Wysocka, A. Mielnikow, B.Michalik, J. Skowronek, Radium balance in discharge waters from coal mines in Upper Silesia region, Proceedings of the NORM IV - Naturally Occurring Radioactive Materials Conference, May 2004, Szczyrk.

[12] B. Michalik, The inventory of mining setling ponds, GIG, 2002 (in Polish)

[13] K. Skubacz, J. Lebecka, S. Chalupnik, B. Michalik, M. Wysocka, Assessment of the radiological impact of the discharge of radium-bearing waters into Golawiecki River - Wiadomosci Gornicze 5/93, 1993, Katowice (in Polish).

[14] S. Chałupnik, B. Michalik, M. Wysocka, K. Skubacz, A. Mielnikow, Contamination of settling ponds and rivers as a result of discharge of radium - bearing waters from Polish coal mines. Journal of Environmental Radioactivity. 54 (2001) 85-98. 